\title{
The origins of metallurgy in China
}

\author{
Lin Meicun \& Xiang Liu*
}

Archaeologists worldwide have shown much interest in the origins of metallurgy in China (e.g. Mei 2005; Hanks et al. 2007; Parzinger 2011; Fan et al. 2012). Around 22001700 BC, the Seima-Turbino Culture originated in the Altai Mountains of Central Asia and spread across the Eurasian steppes (Chernykh 2004, 2008). The most iconic artefact of this culture is the socketed spearhead with single side hook; these have been found across the Eurasian steppes (Figure 1: 1-2). Two new observations of these spearheads suggest that Seima-Turbino metal-casting technology was responsible for the development of metallurgy in China.

\section{Investigation and alloy compositions}

The earliest metal spearheads from northern China (Figure 1: 4-5 \& 7-10) can be classified into two types. Type I is the Seima-Turbino spearhead, which has a hook and a triple-line decoration near the end of the hook (Figure 1: $4 \& 6$ ). Type II is the Chinese imitation of Type I, with a hook and a ring on opposite sides, but lacking the triple-line decoration (Lin 2015; Figure 1: 7, from the Qijia Culture at Shenna).

Recent research on cultural exchanges between the Seima-Turbino and other Bronze Age cultures tested 16 pieces of Seima-Turbino spearhead fragments using XRF (Liu 2015). Table 1 shows that nine were copper, five were copper-arsenic $(\mathrm{Cu}-\mathrm{As})$ alloys and only two were copper-tin (Cu-Sn) alloys. Analysis of metal artefacts from the Erlitou site showed that six were bronze, four were copper-lead-tin $(\mathrm{Cu}-\mathrm{Pb}-\mathrm{Sn})$ alloys, two were copper and only one was a Cu-As alloy (Jin 2000).

Previous research has shown that metal artefacts in central China were dominated by $\mathrm{Cu}-$ Sn alloys (Table 2), and artefacts made of $\mathrm{Cu}$ and $\mathrm{Cu}$-As alloys are less common. $\mathrm{Cu}-\mathrm{Sn}$ alloy artefacts from the Erlitou site account for 76.9 per cent. In contrast, only 12.5 per cent of Seima-Turbino-style spearheads were of $\mathrm{Cu}-\mathrm{Sn}$ alloy. The proportion of $\mathrm{Cu}$ (31.25 per cent) and $\mathrm{Cu}-\mathrm{As}$ (56.25 per cent) spearheads stands at 87.5 per cent (Table 2). Metal artefacts of the Qijia Siba Cultures in Gansu and Qinghai provinces (which exhibit earlier features than Erlitou sites) were dominated by $\mathrm{Cu}$ and $\mathrm{Cu}-\mathrm{As}$ alloys (Sun \& Han 1997). In terms of metal composition, therefore, the Seima-Turbino complex in China demonstrates the early stage of bronze-casting technology. The technology of the Erlitou site was, however, already at a more advanced stage.

Among the 16 earliest spearheads so far known, only six have archaeological provenance: one from the Shenna site and four from the Longshan Culture layer (c. 2600-1900 BC) of the Xiawanggang site in Henan (Lin 2015). This latter site also yielded a spearhead

\footnotetext{
* School of Archaeology and Museology, Peking University, Yiheyuan Road \#5, Beijing, China Author for correspondence (Email: liuxiangscofy@sina.com)
} 


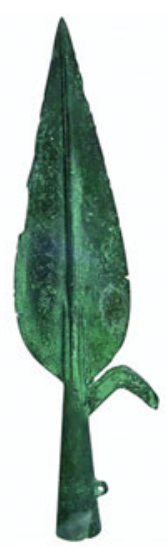

1 Ural

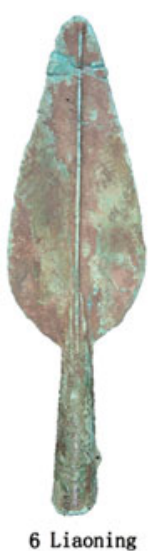

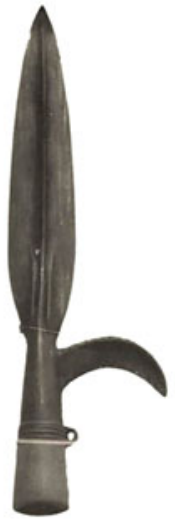

2 Altai

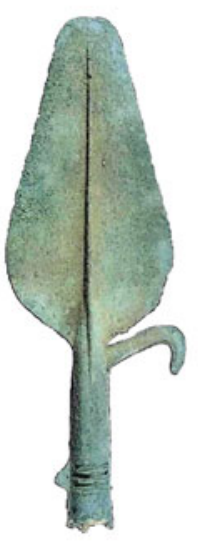

7 Qinghai

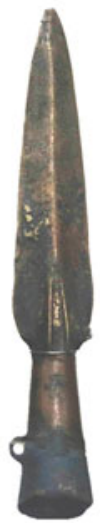

3 Altai

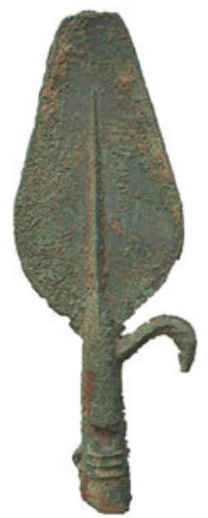

8 Gansu

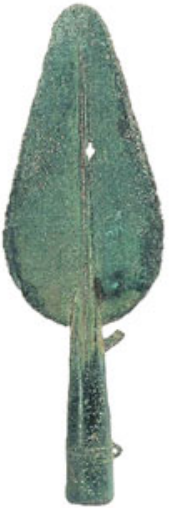

4 Shanxi

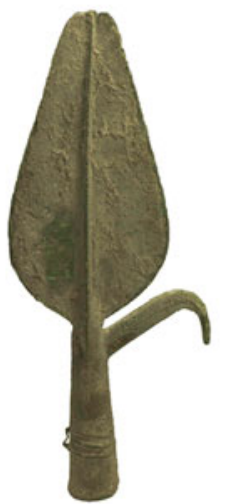

9 Shaanxi

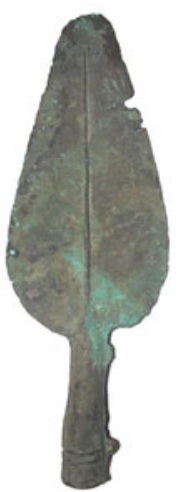

5 Shanxi

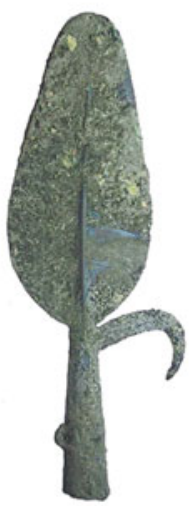

10 Henan

Figure 1. The Seima-Turbino spearheads and their imitations from the Ural Mountains to northern China.

hook fragment from the Erlitou Culture layer (Henan Institute of Archaeology 1989). That spearhead was discarded during the Bronze Age of the Erlitou Culture (c. 1900-1500 BC) (Liu \& Chen 2012).

\section{The jade pendants}

One spearhead from the western Liao River area (with no archaeological context) is housed at the Chaoyang Museum in Liaoning. Our research suggests that it was unearthed together with a semi-annular jade pendant (of jade-huang), by a local farmer. This is attributed to the Taosi Culture (c. 2500-1800 BC) (Gu 2015), a date contemporaneous with the Lower Xiajiadian Culture (c. 2000-1400 BC).

Strassberg (2003; Shan Hai Jing) describes semi-annular jade pendants as part of ritual ware from the Chinese Xia dynasty. He recounts that: "In his [the Xia sovereign, Qi] left hand, he held a feathered pennant, in his right, a jade ring, and he wore a jade semicircle [read, semi-annular jade pendant] on his belt" (Strassberg 2003: 168). The earliest (C) Antiquity Publications Ltd, 2017 
Table 1. The element contents of Seima-Turbino spearheads.

Element contents $/ w t \%$

No. Place

Type $\mathrm{Cu}$ As $\mathrm{Sn} \quad \mathrm{Pb} \quad \mathrm{Bi} \quad \mathrm{Fe}$ Ag Others Alloy type

1 Shanxi Crafts Museum

2 Chaoyang Museum, Liaoning

3 Nanyang Museum, Henan \#1

4 Shanxi Museum

5 Shenna Site, Qinghai

6 Xiawanggang Site, Henan \#1

7 Xiawanggang Site, Henan \#2

8 Xiawanggang Site, Henan \#3

9 Xiawanggang Site, Henan \#4

10 Datong Museum, Qinghai

11 Nanyang Museum, Henan \#2

12 Shaanxi Historical Museum

13 Gansu Museum

14 Gansu Museum

15 National Museum

16 Nanyang Museum, Henan \#3

$\begin{array}{cccccccccl} & 97.1 & - & 1.3 & - & 0.2 & - & - & 1.4 & \mathrm{Cu} \\ \mathrm{I} & 92.9 & - & 6.4 & - & - & 0.2 & - & 0.5 & \mathrm{Cu}-S n \\ & 93.5 & 3.0 & 0.4 & 0.3 & 0.8 & 0.5 & 0.9 & 0.7 & \mathrm{Cu}-\mathrm{As} \\ & 96.0 & 0.3 & 3.2 & - & - & - & - & 0.5 & \mathrm{Cu}-S n \\ & - & - & - & - & - & - & - & - & \mathrm{Cu} \\ \mathrm{II} & 87.2 & 10.3 & - & - & 1.8 & 0.4 & - & 0.4 & \mathrm{Cu}-\mathrm{As} \\ & 94.4 & 4.0 & - & - & 0.1 & 0.8 & - & 0.5 & \mathrm{Cu}-\mathrm{As} \\ & 96.3 & 11.6 & - & 0.5 & 0.2 & 0.9 & - & 0.4 & \mathrm{Cu}-\mathrm{As} \\ & - & - & - & - & - & - & - & - & \mathrm{Cu} \\ & 99.1 & - & 0.3 & - & - & - & - & 0.6 & \mathrm{Cu} \\ & 97.3 & 1.1 & 0.4 & 0.2 & 0.3 & - & - & 0.5 & \mathrm{Cu} \\ & - & - & - & - & - & - & - & - & \mathrm{Cu} \\ & 97.5 & 0.7 & - & - & - & - & - & 1.8 & \mathrm{Cu} \\ 94.7 & 0.4 & & & & 1.7 & & 3.2 & \mathrm{Cu} \\ 95.3 & 2.6 & & & & & & 2.1 & \mathrm{Cu}-\mathrm{As} \\ 96.7 & 0.4 & 1.4 & - & - & 0.9 & - & 0.6 & \mathrm{Cu}\end{array}$

Table 2. The element contents of metal artefacts of the Erlitou Culture (Jin 2000).

\begin{tabular}{llcccccccc}
\hline & & \multicolumn{7}{c}{ Element contents/wt\% } \\
\cline { 5 - 7 } No. & Implements & Phase & Cu & As & Sn & Pb & Ag & Others & Alloy type \\
\hline & & & & & & & & & \\
1 & Fragment & II & 90.7 & 0.1 & 7.4 & 1.3 & 0.2 & 0.3 & Cu-Sn \\
2 & Bronze block & II & 96.3 & 0.8 & 2.0 & 0.2 & 0.1 & 0.6 & Cu-Sn \\
3 & Hairpin & II & 97.5 & 0.1 & 0.2 & 0.6 & 0.1 & 1.5 & Cu \\
4 & Cone & III & 94.0 & 4.5 & 0.3 & - & 0.1 & 1.1 & Cu-As \\
5 & Bronze block & III & 94.3 & 0.6 & 1.5 & 1.2 & 0.6 & 1.8 & Cu-Sn \\
6 & Knife & III & 82.3 & 0.1 & 15.4 & 1.3 & 0.2 & 0.7 & Cu-Sn \\
7 & Fragment & IV & 96.0 & 0.3 & - & 1.5 & 0.2 & 2.0 & Cu \\
8 & Cone & IV & 96.6 & 0.1 & 1.6 & 1.4 & 0.1 & 0.2 & Cu-Sn \\
9 & Fragment & IV & 86.3 & 0.2 & 4.1 & 1.6 & 0.1 & 7.7 & Cu-Sn \\
10 & Ring & IV & 67.2 & 1.8 & 9.4 & 20.7 & 0.2 & 0.7 & Cu-Sn-Pb \\
11 & Jia (round-mouthed wine & IV & 64 & 0.1 & 6.6 & 26.7 & 0.3 & 2.3 & Cu-Sn-Pb \\
& vessel with three legs) & & & & & & & & \\
12 & He (round vessel with a & IV & 62.8 & 0.1 & 13.9 & 22.3 & 0.2 & 0.7 & Cu-Sn-Pb \\
& closed spout) & & & & & & & & \\
13 & Jia & IV & 90.0 & 0.2 & 5.0 & 4.5 & 0.3 & - & Cu-Sn-Pb \\
\hline
\end{tabular}

(securely dated) semi-annular jade pendant dates to the Neolithic period (2200-1600 BC) in northern China. This type of ornament has been found at many early Bronze Age sites, such as the Qijiang Culture sites in Qinghai and Gansu provinces, the Longshan Culture sites in Shaanxi province and the Taosi Culture sites in Shanxi province. The ornaments can 


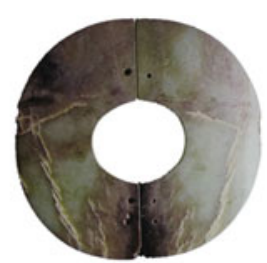

1 Shanxi

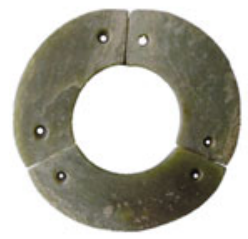

5 Qinghai

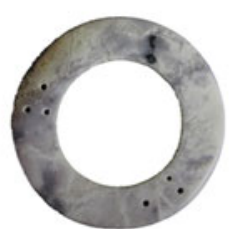

2 Shanxi

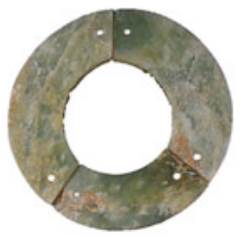

6 Gansu

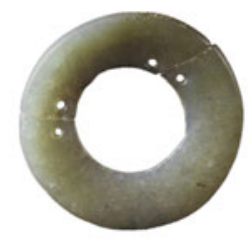

3 Shanxi

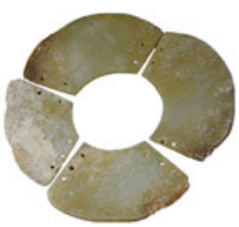

7 Shaanxi

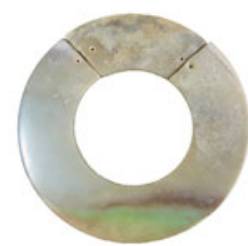

4 Liaoning

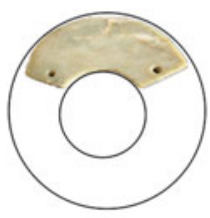

8 Henan

Figure 2. The semi-annular jade pendants from the Neolithic to the Bronze Age in China.

be divided into three groups. The first is represented by two semi-annular jade pendants, dated to the Taosi Culture (2500-1800 BC) (Figure 2: 1-2). The second group refers to the three divided ring pendants (Figure 2: 5-6), which are dated to the Bronze Age Qijia Culture in Qinghai and Gansu provinces (2200-1600 BC) (Liu \& Chen 2012; Gu 2015). The third group are jade ring pendants dating to the time between the first two groups (Figure 2: 3-4).

According to our investigation, the spearhead was excavated along with the semi-annular jade pendant. We could, therefore, conclude that they are of the same date. Through the study of the semi-annular jade pendant, the date of Seima-Turbino spearheads in China was further determined. (Jade-huang of this type was also found in the Taosi and Qijia Cultures.) The semi-annular jade pendant is, however, traditionally a ritual object in China. The archaeological association of the pendant with the Seima-Turbino-style spearhead suggests a transitional function for the latter-from weapon to ritual object.

\section{Discussion and conclusion}

To develop the theory on the origin of Chinese metallurgy further, two observations have been made. First, a chronological observation suggests that the early spearheads have a narrower head in the shape of a willow leaf with a hook and triple-line decorations (Figure 1: 2-3), whereas the later spearheads have a wider willow-leaf-shaped head but retain the triple-line decoration (Figure 1: 1). The former type is similar to south Siberian Okunevo culture spearheads (c. 2400-1800 BC), while examples of the latter type are from the Rostovka Cemetery near Omsk (Figure 1: 1) (Chernykh 1992; Svyatko et al. 2009).

Spearheads of the latter type have also been discovered in China (Figure 1: 4). These Chinese imitations are, however, in the shape of a broad leaf, without the triple-line (C) Antiquity Publications Ltd, 2017 


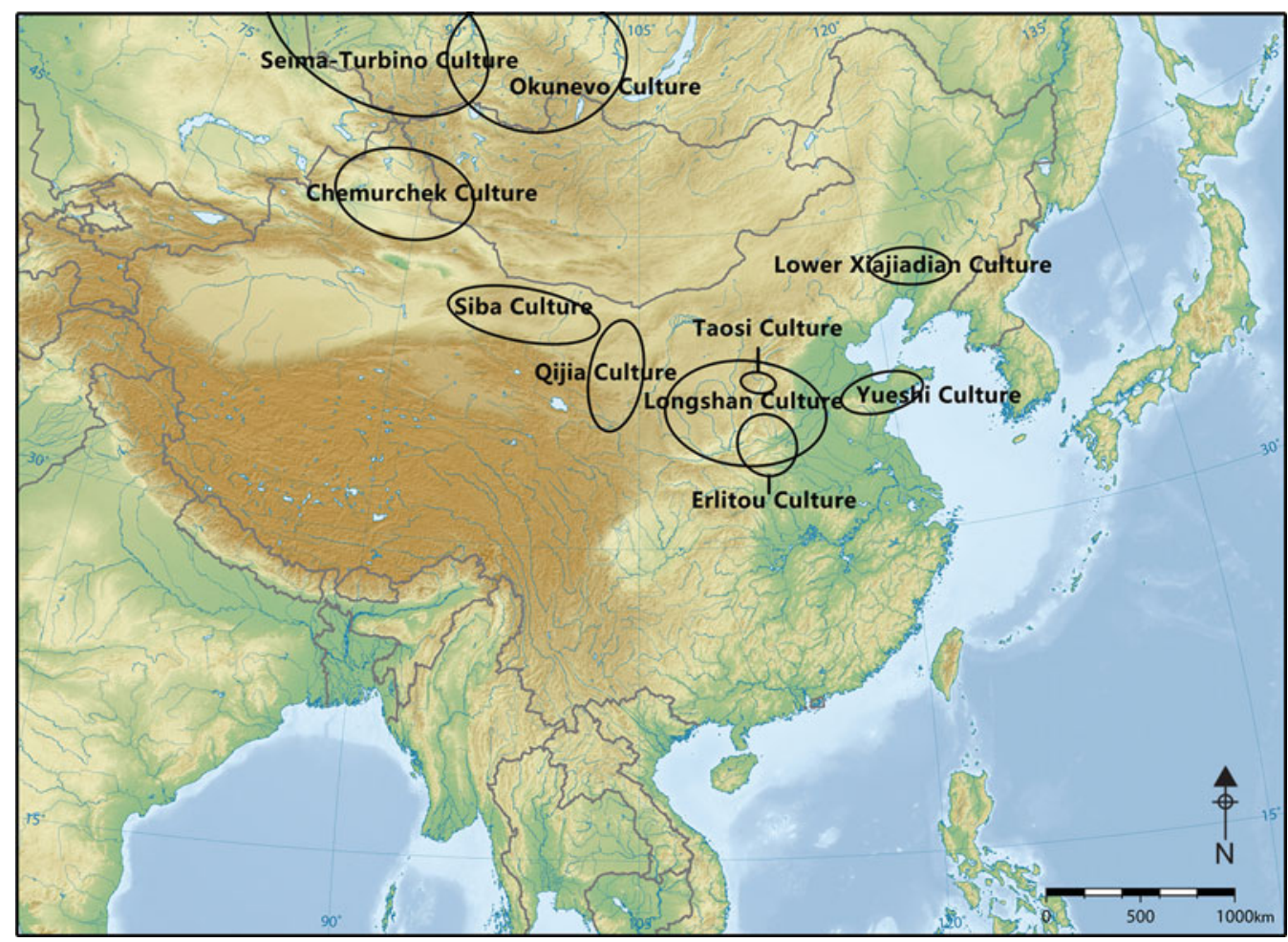

Figure 3. A sketch map of cultures from the Neolithic to the Bronze Age in China.

decoration. The metal spearhead from Chaoyang has a narrower head in the shape of a willow leaf but lacks a hook (Figure 1: 6). This is the same form as the Rostovka Cemetery spearheads, and similar to the Seima-Turbino spearhead housed in the Shanxi Crafts Museum. Examination of the Chaoyang spearhead indicates that it was made of a $\mathrm{Cu}-\mathrm{Sn}$ alloy.

The Niuheliang site, which yielded evidence for Chinese bronze casting, is very valuable to the study of the origins of Chinese metallurgy ( $\mathrm{Li}$ et al. 1999). Although this site was initially dated to the Hongshan Culture (c. 4500-3000 BC) (Liu \& Chen 2012), radiocarbon analysis has placed it at $3300 \pm 300$ to $3494 \pm 340 \mathrm{cal} \mathrm{BC}$, roughly correlating in date to the Lower Xiajiadian levels at the site (An 2003; Gu 2015).

These new observations suggest that the distribution of metal spearheads from the Seima-Turbino Culture to northern China represents the diffusion and spread of the metallurgical technique. From the metallurgical perspective in particular, the bronze casting of spearheads indicates the origin of piece-mould casting and core-casting technology, which influenced the bronze vessel casting method in China. We therefore suggest that the early Chinese metallurgy of the Lower Xiajiadian Culture in the western Liao River area can be linked to the Seima-Turbino Culture; this technique had spread from the Altai Mountain area to northern China via the Taosi Culture. After spreading to the Lower Xiajiadian 
Culture, it finally arrived at the Qijia Culture of Qinghai and Gansu provinces in the west (Figure 3).

\section{References}

AN, Z.M. 2003. Restudy of the Niuheliang site-a group of uncontemporary cultural remains and discussion of the hypothesis of 'Dawn of civilization'. Archaeology and Cultural Relics 1: 17-20.

Chernykh, E.N. 1992. Ancient metallurgy in the USSR. London: Cambridge University Press.

- 2004. Ancient metallurgy of northeast Asia: from Ural to the Sain-Altai, in K.M. Linduff (ed.) Metallurgy in ancient Eastern Eurasia from Ural to the Yellow River: 25-30. Lewiston: Edwin Mellen.

- 2008. Formation of the Eurasian 'Steppe Belt' of stockbreeding cultures. Archaeology, Ethnology and Anthropology of Eurasia 35(3): 36-53. https://doi.org/10.1016/j.aeae.2008.11.003

Fan, X.P., G. Harbottle, Q. GaO, W.R. Zhou, Q.M. GonG, H. WANG, X.H. YU \& C.S. WANG. 2012. Brass before bronze? Early copper-alloy metallurgy in China. Journal of Analytical Atomic Spectrometry 5: 821-26.

Gu, F. (ed.). 2015. The complete collection of unearthed jades in China (volumes 3-5). Beijing: Science.

Hanks, B.K., A.V. Epimakhov \& C. Renfrew. 2007. Towards a refined chronology for the Bronze Age of the southern Urals, Russia. Antiquity 81: 360-61. https://doi.org/10.1017/S0003598X00095235

Henan Institute of Archaeology. 1989. Xiawanggang site in Xichuan. Beijing: Wenwu chubanshe.

Jin, Z.Y. 2000. Scientific research on the bronzes of the Erlitou Culture and exploration of the Xia civilization. Cultural Relics 1: 79.
LI, Y.X., R.F. HaN, W.B. BaO \& T.M. Chen. 1999. Remains of the bronze-casting furnace unearthed at Niuheliang. Cultural Relics 12: 50.

LIN, M.C. 2015. New archaeological evidence on the origin of Chinese bronze cultures, in Y. Taishan \& L. Jinxiu (ed.) Eurasian studies (volume III): 1-12. Sydney: Asian Publishing Nexus.

Liu, L. \& X.C. Chen. 2012. The archaeology of China. London: Cambridge University Press.

Liu, R. 2015. The alloy compositions of Seima-Turbino spearheads in China. Cultural Relics 10: 79.

MeI, J.J. 2005. Qijia and Seima-Turbino: the question of early contacts between northwest China and the Eurasian Steppe. Bulletin of the Museum of Far Eastern Antiquities 75: 31-54.

PARzInger, H. 2011. Die frühen Völker Eurasiens: Vom Neolithikum bis zum Mittelalter. Berlin: C.H. Beck.

Strassberg, R.E. 2003. A Chinese bestiary: strange creatures from the guideways through mountains and seas. Berkeley: University of California Press.

Sun, S.Y. \& R.B. Han. 1997. Studies of early bronze objects from Gansu in terms of their casting and manufacturing techniques. Cultural Relics 7: 75.

Svyatko, S.V., J.P. Mallory, E.M. Murphy, A.V. Polyakov, P.J. Reimer \& R.J. Schulting. 2009. New radiocarbon dates and a review of the chronology of prehistoric populations from the Minusinsk Basin, southern Siberia, Russia. Radiocarbon 51: 243-73. https://doi.org/10.1017/S0033822200033798 